\title{
The Role of Equity Financing on the Profitability of Indonesian Islamic Banks
}

\author{
Agus Widarjono ${ }^{{ }^{*}}$ \\ ${ }^{1}$ Department of economics, Faculty of Business and Economics, Universitas Islam \\ Indonesia, Yogyakarta
}

Submitted: 26 July, 2021; Accepted: 19 January, 2022; Published: 24 January, 2022

\begin{abstract}
Islamic banks provide financing in the form of equity financing and non-equity financing. Equity financing is profit-loss sharing financing which is the main core of Islamic bank business consisting of Mudharabah and Musyarakah. This paper examines the extent to which equity financing affects the profitability of Islamic banks in Indonesia with the control variables consisting of bank-specific variables such as capital adequacy ratio, cost-income ratio, non-performing financing, and macroeconomic conditions such as domestic output, exchange rate. This study employs aggregate data of Islamic banks from January 2010 to December 2019. The estimation method is the Autoregressive distributed lag (ARDL) model. The results prove evidence of the long-run relationship between the dependent and independent variables. The results show that total equity financing increases Islamic banks' profitability in Indonesia, but only Musyarakah financing significantly boosts profitability. Furthermore, the bank-specific variables affecting profits are capital, efficiency, and nonperforming financing. High capital adequacy ratio (CAR) reduces profit and inefficient Islamic banks and non-performing financing lower profit. Evidence also highlights that worse economic conditions through the economic downturn and sharp depreciation obviously lower the profitability of Islamic banks. These results imply that Islamic banks must capitalize on Musyarakah financing to support the performance of Islamic banks.
\end{abstract}

Keywords: Islamic banks, equity financing, mudharabah, musyarakah, profitability 


\section{INTRODUCTION}

Islamic Bank is an intermediary financial institution based on sharia or Islamic concepts. Under Law No. 21 of 2008 concerning Islamic banking, financing provided by Islamic banks is the provision of funds or equivalent claims. Islamic bank financing is grouped into profit-loss sharing (PLS) financing and non-profit loss-sharing (PLS) financing. The first financing is equity financing in the form of Mudharabah (profit sharing) and Musyarakah (joint venture). The second financing is sales principles such as Murabahah (resale with fixed profit), Ijarah (leasing contract), Isthisna (manufacturing contract), Salam (forward contract), and Qardh (goodwill contract).

Islamic banking is still relatively small in the Indonesian banking industry, both in numbers and assets. However, Islamic banking in Indonesia has experienced rapid development. Based on the Financial Services Authority data, there is a positive growth in assets and third-party funds. Total assets amounted to IDR 67,436 trillion and 524.564 trillion in 2010 and 2019, respectively while total third-party funds amounted to IDR 76.036 trillion and 416.942 trillion. Furthermore, the financial performance of Islamic banks also sounds good. The average return on asset (ROA) and capital adequacy ratio (CAR) were $1.528 \%$ and $16.24 \%$, respectively from the period 2010 to 2019 . In addition, according to the Indonesia Financial Services Authority, Non-performing financing, which measures financing risk, was also low at $3.78 \%$, which is lower than the maximum threshold of $5 \%$.

As a new banking industry and due to the rapid development of Islamic banking has attracted researchers to explore the performance of Islamic banks in Indonesia. This research on the financial performance of Islamic banks is important because as part of the financial intermediary in Indonesia, Islamic banks are also inevitable to economic shocks from both domestic and foreign shocks. The East Asian Financial crisis in 1998 caused many banks to collapse, resulting in an economic crisis. Likewise, the world financial crisis in 2008 affected the Indonesian banking Industry.

Many studies have been conducted to examine the financial performance of Islamic banking with various research themes such as profitability, stability, efficiency, and nonperforming financing. Evidence reveals that the internal and external factors influence Islamic banks' profability. Internal factors are bank-specific factors consisting of assets, CAR, financing, efficiency, and non-performing financing (NPF). Assets and financing positively affect profitability while inefficiency and NPF have a negative effect on profitability (Trinugroho et al., 2017; Sutrisno \& Widarjono, 2018). Moreover, external factors are macroeconomic conditions, comprising exchange rate and GDP. The GDP positively affects but depreciation negatively links profitability (Widarjono, 2020).

Numerous empirical studies have also analyzed the performance of Islamic rural banks as regional banks. Warninda (2014) documented that equity financing (Mudharabah and Musyarakah) and non-equity financing (Murabahah) positively affect profitability but NPF 
negatively affects profitability. The macroeconomic variable that affects profit is the money supply. Other empirical research indicated that the bank-specific variables, namely assets and CAR, positively affect profits. Gross Regional Domestic Products has a positive effect but inflation negatively affects profit (Widarjono, Anto, \& Fakhrunnas, 2021).

In addition to the profit theme, financing risk is an important topic to study because Islamic banks are an infant financing industry, so that high non-performing financing certainly reduces bank profits. Several studies report that impaired financing of Islamic commercial banks is affected by CAR and operating efficiency to which high CAR lowers NPF but inefficient operating boots high NPF (Setiawan \& Bagaskara, 2016). More importantly, high concentrated financing leads to high NFP due to high financing risk (Widarjono \& Rudatin, 2021). Some studies are also interested in examining the financing risk of Islamic rural banks since they face high impaired financing. NPF negatively links to the larger bank and high capital (Muhammad, Suluki, \& Nugraheni, 2020). In addition, Income diversification generates low impaired financing (Widarjono, Anto, \& Fakhrunnas, 2020).

This paper aims to explore the role of equity financing on Islamic banks profitability in Indonesia. This research is vital because the initial concept of Islamic banking is a financing system based on profit-loss sharing contracts (Azmat, Skully, \& Brown, 2015). Financing with PLS contacts such as Musyarakah and Mudharabah creates justice for the Islamic banks and their customers. However, Mudharabah and Musyarakah are not the main choices for Indonesian's Islamic banks and Islamic customers. Murabahah financing is a priority for customers and Islamic banks because it is easy to implement even though it has decreased recently. Data indicated that the ratio of equity financing and Murabahah financing to total financing were $29.05 \%$ and $70.94 \%$, respectively, in 2013 but both financings were $48.24 \%$ and $51.78 \%$, respectively in 2019 .

Several studies have analyzed the impact of financing on the profitability of Indonesian Islamic banks. However, some previous empirical studies included total financing contracts but did not distinguish between PLS and non-PLS financings such as Sriyana (2015), Hosen and Rahmawati (2016), Widarjono (2018), Aminah et al. (2019), and Widarjono and Anto (2020). Indeed, some studies have analyzed the role of PLS in banking profits, but they did not include all Islamic banks as the object of studies, such as Risfandy (2018) and Risfandy et al. (2020). This paper analyzes the role of equity financing on Islamic banks' profitability using aggregated data on Islamic banking in Indonesia. More importantly, Mudharabah and Musyarakah as equity financing are slightly different. Accordingly, this study further explores the extent to which each equity financing affects Islamic banks' profitability.

\section{METHOD}

This paper investigates the effect of equity financing, together with some explanatory variables consisting of internal bank factors such as CAR, efficiency, NPF, and external factors such as national output and exchange rate, on the profitability of Indonesian Islamic banks. We 
utilize the aggregate Islamic banks, using monthly data and covering from January 2010 to December 2019. The data are sourced from the Indonesian Financial Service Authority. Our paper follows the existing studies to investigate the profitability of Islamic banks such as Trinugroho et al. (2017), Sutrisno and Widarjono (2018), and Widarjono (2018). The Autoregressive Distributed Model (ARDL) is applied. We apply it due to some benefits. First, the ARDL model does not require all variables are integrated in the same order. Second, as a dynamic regression model, it can explore short-run and long-run conditions. The model of this study can be expressed in the following regression:

$\mathrm{ROA}_{\mathrm{t}}=\emptyset_{0}+\emptyset_{1} \mathrm{PLS}_{\mathrm{t}}+\emptyset_{2} \mathrm{CAR}_{\mathrm{t}}+\emptyset_{3} \mathrm{CIR}_{\mathrm{t}}+\emptyset_{4} \mathrm{NPF}_{\mathrm{t}}+\emptyset_{5} \mathrm{LIPI}_{\mathrm{t}}+\emptyset_{6} \mathrm{LEXC}_{\mathrm{t}}+\mathrm{e}_{\mathrm{t}}$

Where ROA is a return on asset measuring profitability, CAR is capital adequacy ratio measuring capital capability, PLS is profit and loss sharing financing measuring equity financing, CIR is a cost-to-income ratio, representing operating efficiency, NPF is nonperforming financing, indicating impaired financing, IPI is industrial production index as a proxy of gross domestic product, and EXC is exchange rate Indonesian Rupiah (IDR) against to US\$. IPI and EXC are expressed in the natural logarithm.

PLS is the equity financing-to-total financing ratio (\%). The role of PLS financing on profitability is possibly arguable. Equity financing contracts as a core financing are subject to moral hazard and asymmetric information. Entrepreneurs may have less effort to run their business and they are likely cheating in reporting their financial statements (Azmat, Skully, \& Brown, 2015). By contrast, entrepreneurs take this equity financing since it is likely a fair financing contract so they could provide more incentive in running their business and generate more profit (Risfandy, 2018). Accordingly, PLS financing links to the positive or negative effect on ROA.

CAR is capital adequacy ratio (\%). CAR represents Islamic banks' ability to conserve their capital capability. Holding more capital through high CAR reflects the risk-averse behaviour of Islamic banks so that financing also declines. Their risk-averse behaviour occurs because the equity financing contract is likely to generate high financing risk due to moral hazards and asymmetric information. By contrast, Islamic banks can expand their financing through low CAR to create more profit(Hamid, 2017). Therefore, CAR may link negatively to ROA.

There are many ways to measure banking efficiency, one of which is operating efficiency. Operating efficiency shows how much it costs to generate income per unit (Trinugroho, Agusman, \& Tarazi, 2014). Therefore, this study applies the cost-to-income ratio (CIR) to calculate the Islamic bank efficiency (\%). The High CIR indicates that the cost to generate per unit income is high. Accordingly, low CIR indicates higher efficiency and vice versa. High CIR causes Islamic banks to generate low margins so that Islamic banks make low profits (Trinugroho, Risfandy, \& Ariefianto, 2018). This paper expects that CIR negatively affects ROA. 
Every Islamic bank as a financial intermediary always faces financing risk. One measure of financing risk that is widely used in Islamic banks is non-performing financing. Non-performing financing (NPF) is the ratio of impaired financing to total financing (\%). The higher the NFP means, the greater the bad financing and it is hard to retrieve. High NPF indicates that the bank will not generate high profits (Ahamed, 2017; Widarjono, Mifrahi, \& Perdana, 2020). Accordingly, this paper hypothesizes NPF negatively affects Islamic banks' profitability.

Output is the production of goods and services produced in a country and is measured by GDP. Monthly GDP data is not available so the industrial production index (IPI) is used as a proxy of GDP. Output upturn indicates improving economic conditions and conversely, output downturn indicates worsening economic conditions. A rising in the output indicates an increase in the production of goods and services increases income and further increases Islamic banks' profitability (Widarjono, 2018). A positive sign is expected in LIPI because economic upturn generates more profit for Islamic bank.

The exchange rate is the price of the domestic currency against foreign currencies. Indonesia relies on raw materials from imported raw materials for domestic production. Depreciation of Rupiah against US\$ indicates that the rupiah weakens against the US\$. Depreciation causes domestic prices to become expensive because of the high cost of imported raw materials. Depreciation thus reduces the ability of banks to generate profits due to high inflation. Therefore, the exchange rate negatively links to Islamic banks' profitability.

We can express the equation (1) in the ARDL model as

$$
\begin{aligned}
\Delta \mathrm{ROA}_{\mathrm{t}} & =\vartheta_{0}+\sum_{\mathrm{i}=1}^{\mathrm{p}} \vartheta_{1 \mathrm{i}} \Delta \mathrm{ROA}_{\mathrm{t}-1}+\sum_{\mathrm{i}=1}^{\mathrm{p}} \vartheta_{2 \mathrm{i}} \Delta \mathrm{PLS}_{\mathrm{t}-1}+\sum_{\mathrm{i}=1}^{\mathrm{p}} \vartheta_{3 \mathrm{i}} \Delta \mathrm{CAR}_{\mathrm{t}-1}+\sum_{\mathrm{i}=1}^{\mathrm{p}} \vartheta_{4 \mathrm{i}} \Delta \mathrm{CIR}_{\mathrm{t}-1}+ \\
& \sum_{\mathrm{i}=1}^{\mathrm{p}} \vartheta_{5 \mathrm{i}} \Delta \mathrm{NPF}_{\mathrm{t}-1}+\sum_{\mathrm{i}=1}^{\mathrm{p}} \vartheta_{6 \mathrm{i}} \Delta \mathrm{LIPI}_{\mathrm{t}-1}+\sum_{\mathrm{i}=1}^{\mathrm{p}} \vartheta_{7 \mathrm{i}} \Delta \mathrm{LEXC}_{\mathrm{t}-1}+\theta_{1} \mathrm{ROA}_{\mathrm{t}-1}+\theta_{2} \mathrm{PLS}_{\mathrm{t}-1}+ \\
& \theta_{3} \mathrm{CAR}_{\mathrm{t}-1}+\theta_{4} \mathrm{CIR}_{\mathrm{t}-1}+\theta_{5} \mathrm{NPF}_{\mathrm{t}-1}+\theta_{6} \mathrm{LIPI}_{\mathrm{t}-1}+\theta_{7} \mathrm{LEXC}_{\mathrm{t}-1}+\mathrm{e}_{\mathrm{t}}
\end{aligned}
$$

where $\Delta$ is the first different (lag), $\vartheta_{1 \mathrm{i}}-\vartheta_{7 \mathrm{i}}$ are the short-run dynamic condition and $\theta_{1}-\theta_{7}$ are the long-run condition. The error correction model of the ARDL model can be written as

$$
\begin{aligned}
\Delta \mathrm{ROA}_{\mathrm{t}}= & \vartheta_{0}+\sum_{\mathrm{i}=1}^{\mathrm{p}} \vartheta_{1 \mathrm{i}} \Delta \mathrm{ROA}_{\mathrm{t}-1}+\sum_{\mathrm{i}=1}^{\mathrm{p}} \vartheta_{2 \mathrm{i}} \Delta \mathrm{PLS}_{\mathrm{t}-1}+\sum_{\mathrm{i}=1}^{\mathrm{p}} \vartheta_{3 \mathrm{i}} \Delta \mathrm{CAR}_{\mathrm{t}-1}+\sum_{\mathrm{i}=1}^{\mathrm{p}} \vartheta_{4 \mathrm{i}} \Delta \mathrm{CIR}_{\mathrm{t}-1}+ \\
& \sum_{\mathrm{i}=1}^{\mathrm{p}} \vartheta_{5 \mathrm{i}} \Delta \mathrm{NPF}_{\mathrm{t}-1}+\sum_{\mathrm{i}=1}^{\mathrm{p}} \vartheta_{6 \mathrm{i}} \Delta \mathrm{LIPI}_{\mathrm{t}-1}+\sum_{\mathrm{i}=1}^{\mathrm{p}} \vartheta_{7 \mathrm{i}} \Delta \mathrm{LEXC}_{\mathrm{t}-1}+\theta_{7} \mathrm{ECT}_{\mathrm{t}-1}+\mathrm{e}_{\mathrm{t}}
\end{aligned}
$$

where $\mathrm{ECT}_{\mathrm{t}-1}$ is lag of error and $\theta_{7}$ is the speed of adjustment coefficient.

There are several steps to estimating the ARDL model. The first step is to test the stationarity of the data. The second step is to estimate the ARDL model using the Ordinary Least Squares (OLS) method. The next step is a cointegration test to determine the long-run relationship between variables applying the bound testing approach. The bound test follows Fstatistics $\left(\mathrm{F}_{\mathrm{PSS}}\right)$. The critical Bound test method consists of the lower bound $\mathrm{I}(0)$ dan upper bound $\mathrm{I}(1)$. A cointegration is found as $\mathrm{F}_{\mathrm{PSS}}$ exceeds I(1). The fourth step is to estimate the ECM model if there is cointegration. The final step is to estimate the long-run coefficients. 


\section{RESULT AND DISCUSSION \\ Descriptive Statistics}

Table 1 reveals the variables studied in this study. The average ROA is 1.52 and is relatively stable with a standard deviation of 0.458 . The maximum ROA value is $2.52 \%$ and the minimum value is $0.08 \%$. The average ROA exceeds the threshold value of $1.5 \%$. However, ROA is the average value for all Islamic banks so it does not reflect the behaviour of each Islamic bank. The average equity financing is $35.181 \%$, meaning that non-equity financing is dominant for Islamic Financing. The average CAR value is $16.247 \%$ and this value is above the threshold value of $15 \%$. Financing risk is also low, with an average value of $3.776 \%$. In general, Islamic banking in Indonesia is quite sound in the banking industry in Indonesia.

Table 1. Descriptive statistics

\begin{tabular}{lllll}
\hline Variable & Mean & Std. Dev. & Maximum & Minimum \\
\hline ROA & 1.528 & 0.458 & 2.520 & 0.080 \\
PLS & 35.181 & 0.061 & 48.220 & 26.579 \\
CAR & 16.247 & 2.351 & 21.390 & 11.070 \\
CIR & 83.814 & 6.695 & 94.380 & 70.430 \\
NPF & 3.776 & 0.802 & 5.540 & 2.220 \\
IPI & 123.389 & 16.447 & 158.000 & 92.320 \\
EXC & 11803.710 & 2116.693 & 15178.870 & 8526.800 \\
\hline
\end{tabular}

\section{Baseline Results}

Prior to estimating the ARDL model, the study checks the stationarity of all variables to determine their order of integration using the unit-root test. This step warrants that each variable is not second-order stationary I(2) to stay away from the spurious regression. In addition, in the existence of $\mathrm{I}(2)$ variables, then the critical F- statistics in the bounding testing approach are not suitable because the bound test assumes that variables are stationary at the level I(0) or at the first differenced level I(1). Therefore, the unit root test is important to guarantee that each variable is integrated of order 0 or 1 . We apply two unit-root tests using Augmented Dickey-Fuller (ADF) and Phillip-Perron (PP) tests with constant and trends. The results of unit-root tests are revealed in table 2. The findings report that ROA, CAR, CIR and LIPI are I(0) and PLS, NPF and LEXC are I(1) but none of them is I(2). These tests imply that the ARDL approach is applicable to estimate the profitability of Indonesian Islamic banks.

Table 2. Unit-root test

\begin{tabular}{lllllllll}
\hline & \multicolumn{3}{c}{ level } & \multicolumn{3}{c}{ difference } \\
\cline { 2 - 8 } Variable & \multicolumn{2}{c}{ ADF } & \multicolumn{2}{c}{ PP } & \multicolumn{2}{c}{ ADF } \\
\hline ROA & $-3.30^{* *}$ & $-3.41^{*}$ & $-3.17^{* *}$ & -3.09 & $-11.13^{* * *}$ & $-11.13^{* * *}$ & $-15.85^{* * *}$ & $-16.18^{* * *}$ \\
PLS & 1.16 & -2.26 & 1.25 & -2.20 & $-4.88^{* * *}$ & $-10.60^{* * *}$ & $-9.76^{* * *}$ & $-10.68^{* * *}$ \\
CAR & -1.80 & -2.24 & -2.27 & $-3.34^{*}$ & $-11.78^{* * *}$ & $-11.73^{* * *}$ & $-13.10^{* * *}$ & $-13.04^{* * *}$ \\
CIR & -1.82 & -2.07 & -2.50 & $-3.47^{* *}$ & $-17.65^{* * *}$ & $-17.58^{* * *}$ & $-20.21^{* * *}$ & $-20.19^{* * *}$ \\
NPF & -1.60 & -1.63 & -2.56 & -2.56 & $-10.83^{* * *}$ & $-10.78^{* * *}$ & $-15.19^{* * *}$ & $-15.12^{* * *}$ \\
LIPI & -0.65 & $-10.51^{* * *}$ & -1.41 & $-10.51^{* * *}$ & $-7.80^{* * *}$ & $-7.78^{* * *}$ & $-63.02^{* * *}$ & $-68.58^{* * *}$ \\
LEXC & -0.78 & -1.62 & -0.77 & -1.59 & $-8.30^{* * *}$ & $-8.26^{* * *}$ & $-8.28^{* * *}$ & $-8.24^{* * *}$ \\
\hline
\end{tabular}

Notes: $* * *, * *, *$ report significance in $1 \%, 5 \%$, and $10 \%$, respectively 
The next step is to estimate the ARDL model as equation (2) using the OLS method. The ARDL model is a dynamic model whose estimation results depend on the selected lag. The maximum lag length in this study is 6. This study uses Akaike Information Criterion (AIC) and Schwarz criteria (SC) methods to select the optimum lag length. The estimation results of the ARDL model are shown in table 3. The ARDL model with the AIC method is $(1,0,2,0,0,0,0)$ while the SC method is $(1,0,0,0,0,0,0)$.

According to the AIC method, 7 out of 10 variables are significant. On the other hand, 7 out of 8 are significant according to the $\mathrm{SC}$ method. The coefficient of determination of $\left(\mathrm{R}^{2}\right)$ the two methods is 0.7700 and 0.7528 , meaning that both AIC and SC methods can explain the ARDL model well. This study uses the Lagrange Multiplier (LM) and Autoregressive Conditional Heteroscedasticity $(\mathrm{ARCH})$ methods to check serial correlation and heteroscedasticity problems. According to the LM and ARCH tests, both AIC and SC methods pass the serial correlation and heteroscedasticity problems. While the coefficient stability test using CUSUM and CUSUM squares is shown in Figures 1 and 2. The CUSUM tests indicate that the estimated parameters are stable. The coefficient stability is not stable using CUSUM Squares but it tends stable. The OLS method produces the best linear unbiased estimator (BLUE) based on the diagnostic tests.

Table 3. ARDL: total equity financing

\begin{tabular}{lllll}
\hline \multirow{2}{*}{ Variable } & AIC method & & SC method & \\
\cline { 2 - 5 } C & Coefficient & t-statistic & Coefficient & t-statistic \\
ROA(-1) & $8.1490^{* * *}$ & 4.1178 & $8.4262^{* * *}$ & 4.1786 \\
PLS & $0.5133^{* * *}$ & 6.5773 & $0.4868^{* * *}$ & 6.1461 \\
CAR & $1.5596^{* *}$ & 2.1831 & $1.8163^{* *}$ & 2.6086 \\
CAR(-1) & -0.0284 & -1.2363 & $-0.0275^{*}$ & -1.6819 \\
CAR(-2) & $-0.0445^{*}$ & -1.6802 & - & - \\
CIR & $0.0641^{* * *}$ & 2.8481 & - & - \\
NPF & -0.0057 & -0.8857 & -0.0081 & -1.2399 \\
LIPI & $-0.1121^{* *}$ & -2.4626 & $-0.1241^{* * *}$ & -2.6943 \\
LEXC & 0.7275 & 1.2853 & $1.1259^{* *}$ & 2.0771 \\
R-squared & $-1.1110^{* * *}$ & -2.6755 & $-1.2927^{* * *}$ & -3.1231 \\
Diagnostic test & 0.7700 & & 0.7528 & \\
LM & & & & \\
ARCH & 1.2195 & $(0.2695)$ & 1.2896 & $(0.5248)$ \\
\hline
\end{tabular}

Notes: $* * *, * *, *$ report significance in $1 \%, 5 \%$, and $10 \%$, respectively

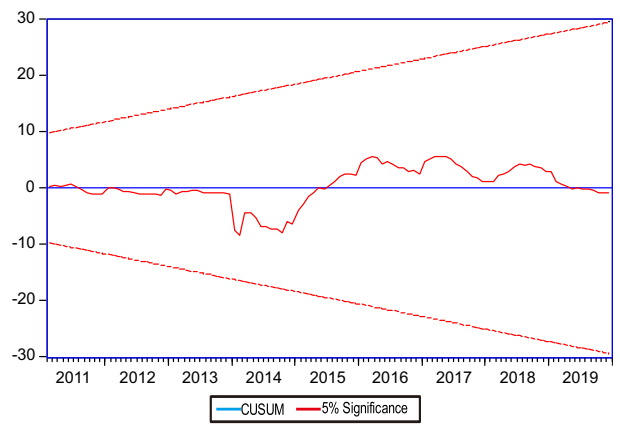




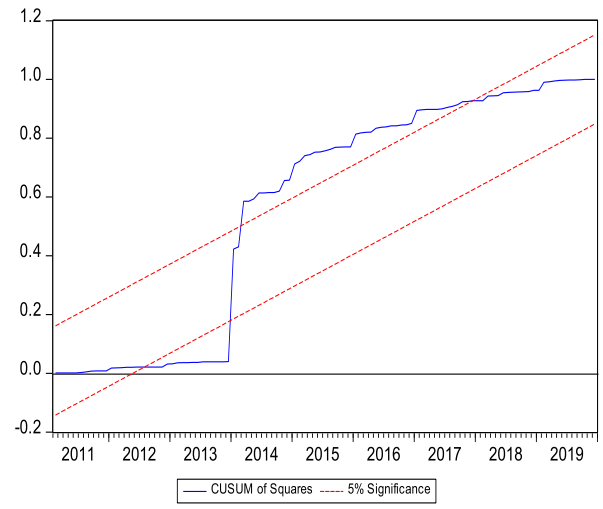

Figure 1. stability test of ARDL with AIC method
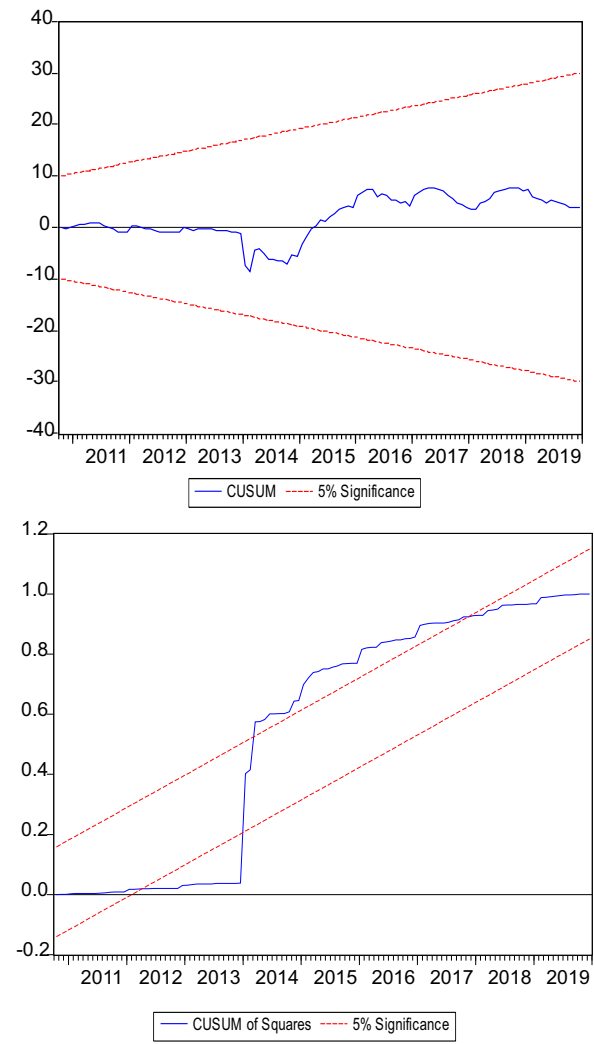

Figure 2. stability test of ARDL with SC method

The null hypothesis of no cointegration is $\theta 1=\theta 2=\theta 3=\theta 4=\theta 5=\theta 6=\theta 7$. Having estimated parameters of ARDL, the next step is the cointegration test using the bound testing method (Pesaran, Shin, \& Smith, 2001) The bound test follows F-statistics $\left(\mathrm{F}_{\mathrm{PSS}}\right)$. The critical Bound test method consists of the lower bound $\mathrm{I}(0)$ dan upper bound $\mathrm{I}(1)$. A cointegration is found as $\mathrm{F}_{\mathrm{PSS}}$ exceeds $\mathrm{I}(1)$. The results of cointegration are revealed in Table $4 . \mathrm{F}_{\mathrm{PSS}}$ are 5.3363 and 5.5745 for the AIC and SC methods, respectively. F $_{\text {PSS }}$ exceeds the upper bound, implying the long-run relationship between the dependent and independent variables. These findings ensure ECM-ARDL model is valid. 
Table 4. Cointegration test

\begin{tabular}{|c|c|c|c|c|}
\hline \multicolumn{2}{|c|}{$\mathrm{F}_{\mathrm{PSS}}$} & \multirow[b]{2}{*}{ alfa } & \multicolumn{2}{|c|}{ Critical value } \\
\hline AIC method & SC method & & Lower bound & Upper bound \\
\hline \multirow[t]{3}{*}{$5.3363 * * *$} & $5.5745 * * *$ & $10 \%$ & 1.99 & 2.94 \\
\hline & & $5 \%$ & 2.27 & 3.28 \\
\hline & & $1 \%$ & 2.88 & 3.99 \\
\hline
\end{tabular}

Notes: $* * *, * *, *$ report significance in $1 \%, 5 \%$, and $10 \%$, respectively

The next step is to estimate the error-correction model (ECM). ECM is a short-run estimation model because of the disequilibrium condition in the behaviour of each economic agent. This disequilibrium is indicated by several variables that are not stationary at the level with the unit-roots test. Due to the disequilibrium in the short run, this ECM model includes the lag error, namely ECT(-1) as a correction variable in the short run to move towards equilibrium condition in the long run. Therefore, the ECM model is valid if the error correction variable is negative and significant. The results of the ECM-ARDL estimation are shown in Table 5. Both AIC and SC methods produce a valid ECM-ARDL model. The lag errors ECT(-1) were negative and significant, but the SC model resulted in a faster adjustment towards equilibrium condition because the coefficient of lag error is higher. The AIC method reports that only the CAR affects ROA in the short run but there is no explanatory variable that affects ROA in the short run for the SC method.

Table 5. ECM-ARDL: total equity financing

\begin{tabular}{lllll}
\hline & \multicolumn{2}{c}{ AIC method } & \multicolumn{2}{c}{ SC method } \\
\cline { 2 - 5 } Variable & Coefficient & t-statistic & Coefficient & t-statistic \\
\hline D(CAR) & -0.0284 & -1.4259 & & \\
D(CAR(-1)) & $-0.0641^{* * *}$ & -3.2173 & & \\
ECT(-1) & $-0.4867 * * *$ & -6.7422 & $-0.5132 * * *$ & -6.8854 \\
R-squared & 0.3367 & & 0.2866 & \\
\hline
\end{tabular}

Notes: $* * *, * *, *$ report significance in $1 \%, 5 \%$, and $10 \%$, respectively

The final step is to estimate the long-run ARDL model to produce the long-run coefficients to which each economy agent adjusts for short-run disequilibrium. Table 6 reports the long-run coefficient of the ARDL model. PLS financing as the main variable in this study is positive and significant with both AIC and SC methods, implying that greater equity financing will increase Islamic banks' profitability. CAR is negative and significant in the SC method, meaning that high CAR reduces profits. As expected, the CIR is negative and significant in the SC method. NPF representing impaired financing negatively affects profitability. Economic upturn positively affects profitability but depreciation negatively links to profitability. According to macroeconomic conditions, good economic conditions boost profitability but worse economic conditions trim down profitability. 
Table 6. Long-run ARDL: total equity financing

\begin{tabular}{lllll}
\hline & \multicolumn{2}{c}{ AIC method } & \multicolumn{2}{c}{ SC method } \\
\cline { 2 - 5 } Variable & Coefficient & t-statistic & Coefficient & t-statistic \\
\hline Constant & $16.7422^{* * *}$ & 4.6348 & $16.4194 * * *$ & 4.7080 \\
PLS & $3.2043^{* *}$ & 2.3072 & $3.5393 * * *$ & 2.7442 \\
CAR & -0.0180 & -0.4885 & $-0.0535^{*}$ & -1.7159 \\
CIR & -0.0118 & -0.9184 & $-0.0158^{*}$ & -1.2941 \\
NPF & $-0.2304^{* * *}$ & -2.6770 & $-0.2418^{* * *}$ & -2.9148 \\
LIPI & $1.4946^{*}$ & 1.3039 & $2.1939^{* * *}$ & 2.0669 \\
LEXC & $-2.2826^{* * *}$ & -2.7544 & $-2.5190^{* * *}$ & -3.1597 \\
\hline
\end{tabular}

Notes: $* * *, * *, *$ report significance in $1 \%, 5 \%$, and $10 \%$, respectively

This empirical study reveals that equity financing has a positive effect on profitability. Theoretically, equity financings are risky due to moral hazards and asymmetric information but equity financings can promote more profitability. Equity financing such as Mudharabah as profit-loss sharing contract and Musyarakah through partnership contract is a fair contract because the loss or profit is shared together, giving stronger incentives for entrepreneurs in running their business so that high profits can be expected (Risfandy, 2018). Our results are in line with the study from Čihák and Hesse (2010) for which financing equity can increase the profits for large Islamic banks. This finding is also supported by the fact that large banks can increase profits due to economics of scale (Ibrahim \& Rizvi, 2017). Consequently, large Islamic banks can diversify financing by increasing financing based on equity financing contracts because Mudharabah and Musyarakah financing results in the same financing risk (Warninda, Ekaputra, \& Rokhim, 2019). Equity financing can increase profits because Islamic banks mainly provide funds to medium and small businesses that make up most business types in Indonesia. They prefer equity financing because of the flexibility in financing repayments (Risfandy et al., 2020).

Now, we turn to bank-specific variables as control variables. First, CAR has a negative effect on Islamic banks' profitability. The higher CAR indicates that Islamic banks are prudential in lending their funds because they must comply with Islamic principles. This condition will reduce financing, lowering the profit rate (Chen, Liang, \& Yu, 2018). Profitability is also related to efficiency, which aligns with previous panel data research (Trinugroho et al., 2017; Widarjono \& Anto, 2020). Operating efficiency reflects good bank management to increase profits. As expected, the NPF reflecting bad financing reduces the profitability of Islamic banks, confirming the previous research(Widarjono, 2018; Sutrisno \& Widarjono, 2018). The high bad financing reduces the ability of banks to expand financing due to the large risk of the previous financing, thereby reducing profits.

The last discussion is the control variable of macroeconomic conditions. Macroeconomic conditions significantly affect micro conditions, including the Islamic banking industry. Good economic conditions encourage banks to expand their business to increase profits. The results clearly show that economic upturn through an increase in domestic production proxy by Industrial production index and Rupiah appreciation can increase profits. Depreciation reduces profits because depreciation increases the cost of production and then reduces profit, supporting the previous study from Widarjono (2018). 


\section{Further Investigation}

Equity financing consists of Mudharabah and Musyarakah. The two financing contracts are slightly different. The first type of financing provides funds for entrepreneurs to manage funds in running their business and the second type of financing needs banks and entrepreneurs to provide funds to manage a project. The previous results do not differentiate between both financings, even though the two financing contracts have different consequences in terms of fund management. The Mudharabah model raises the issue of moral hazard and asymmetric information. It is important to distinguish between both financings in their role in the profitability of Islamic banks. Therefore, we further explore the extent to which each equity financing affects Islamic banks' profitability. Mudharabah (MUD) is the ratio of Mudharabah financing to total financing while Musyarakah (MUS) is the ratio of Musyarakah financing to total financing.

Tables 7-9 report the estimation results of the ARDL model. The AIC method produces an ARDL model $(1,0,3,0,0,0,0)$ while the SC method generates an ARDL $(1,0,0,0,0,0,0)$. Both models pass no serial correlation through the LM test and heteroscedasticity through the $\mathrm{ARCH}$ test so that the OLS produces an unbiased and efficient estimator. The cointegration test results show that the AIC and SC methods reject the null hypothesis of no cointegration. These results imply a long-run relationship exists between the dependent and independent variables. The results of the ECM-ARDL estimation are shown in table 8. The ECM model is valid and the only CAR affect profits in the short-run.

Table 7.ARDL: Mudharabah and Musyarakah financing

\begin{tabular}{lllll}
\hline & \multicolumn{3}{c}{ AIC method } & \multicolumn{2}{c}{ SC method } \\
\cline { 2 - 5 } Variable & Coefficient & t-Statistic & Coefficient & t-Statistic \\
\hline C & $12.1621^{* *}$ & 2.2422 & $13.2001^{* *}$ & 2.4704 \\
ROA(-1) & $0.5492^{* * *}$ & 6.6664 & $0.4763^{* * *}$ & 5.9558 \\
MUD & -0.0194 & -0.6364 & -0.0094 & -0.3190 \\
MUS & 0.0155 & 1.5782 & $0.0239^{* *}$ & 2.6074 \\
CAR & -0.0077 & -0.3092 & $-0.0312^{*}$ & -1.8588 \\
CAR(-1) & $-0.0517^{*}$ & -1.9437 & & \\
CAR(-2) & $0.0890^{* * *}$ & 3.1723 & & \\
CAR(-3) & -0.0350 & -1.4014 & & -1.2260 \\
OER & -0.0037 & -0.5673 & -0.0080 & -2.0876 \\
NPF & -0.0760 & -1.4628 & $-0.1048 * *$ & 0.9609 \\
LIPI & 0.4824 & 0.6872 & 0.6828 & -3.1160 \\
LEXC & $-1.4298^{* * *}$ & -2.7549 & $-1.5696^{* * *}$ & \\
R-squared & 0.7775 & & 0.7549 & \\
Diagnostic test & & & & \\
LM & 0.2948 & $(0.5872)$ & 1.6394 & $(0.2004)$ \\
ARCH & 0.5317 & $(0.4659)$ & 1.3280 & \\
Cointegration test & & & & \\
F & $3.8506^{* * *}$ & & $5.0562 * * *$ & \\
\hline
\end{tabular}

Note: $* * *, * * *$ report significance in $1 \%, 5 \%$, and $10 \%$, respectively. P-values are shown in parantheses. 
Table 8. ECM-ARDL: Mudharabah and Musyarakah financing

\begin{tabular}{lllll}
\hline & AIC method & & SC method & \\
\cline { 2 - 5 } Variable & Coefficient & t-Statistic & Coefficient & t-Statistic \\
\hline $\mathrm{D}(\mathrm{CAR})$ & -0.0077 & -0.3705 & & \\
$\mathrm{D}(\mathrm{CAR}(-1))$ & $-0.0540^{* * *}$ & -2.6693 & & \\
$\mathrm{D}(\mathrm{CAR}(-2))$ & 0.0350 & 1.6131 & & \\
ECT $(-1)$ & $-0.4508^{* * *}$ & -6.1070 & $-0.5237^{* * *}$ & -6.9868 \\
R-squared & 0.3578 & & 0.2926 & \\
\hline
\end{tabular}

Note: $* * *, * *, *$ report significance in $1 \%, 5 \%$, and $10 \%$, respectively

We turn to discuss the long-run coefficients, representing the long-run equilibrium condition. Our main concern is the role of Mudharabah and Musyarakah on the Islamic banks' profitability. Mudharabah is negative but not significant but Musyarakah is positive and significant. This finding reports that only Musyarakah financing can increase the profitability of Islamic banks. The role of Musyarakah financing in encouraging profit also occurs in Islamic rural banks (Warninda, 2014). Our finding is in line with the fact that entrepreneurs prefer to use Musyarakah contracts than Mudharabah because the former contracts pose the same responsibilities in running their business (Risfandy, 2018). Interestingly, the risk of Musyarakah financing is U-shape reserve. The number of NPFs is high when the proportion of Musyarakah financing to total financing is small, but the NPF decrease as the proportion of Musyarakah financing increases (Warninda, Ekaputra, \& Rokhim, 2019). The bank-specific variables such as CAR and bad impaired financing have a negative effect on profits. Deteriorating economic conditions due to the depreciation of the rupiah also reduced profits.

Table 9. Long-run ARDL: Mudharabah and Musyarakah financing

\begin{tabular}{lllll}
\hline & \multicolumn{3}{c}{ SIC method } & \multicolumn{2}{c}{ SC method } \\
\cline { 2 - 5 } Variable & Coefficient & t-Statistic & Coefficient & t-Statistic \\
\hline C & $26.9768^{* *}$ & 2.3084 & $25.2056^{* *}$ & 2.5896 \\
MUD & -0.0430 & -0.6312 & -0.0179 & -0.3195 \\
MUS & $0.0344^{* *}$ & 1.6780 & $0.0457^{* * *}$ & 2.7547 \\
CAR & -0.0120 & -0.2727 & $-0.0596^{* *}$ & -1.9067 \\
OER & -0.0082 & -0.5821 & -0.0153 & -1.2776 \\
NPF & $-0.1685^{*}$ & -1.5638 & $-0.2002^{* *}$ & -2.1834 \\
LIPI & 1.0700 & 0.6844 & 1.3038 & 0.9537 \\
LEXC & $-3.1714^{* * *}$ & -2.7612 & $-2.9971^{* * *}$ & -3.2012 \\
\hline
\end{tabular}

Note: $* * *, * *, *$ report significance in $1 \%, 5 \%$, and $10 \%$, respectively

\section{Robustness Check}

Finally, we must verify whether our findings are robust to other methods. To do so, we perform robustness tests with multiple regression models using ordinary least squares (OLS) methods. Our study employs the heteroscedasticity and autocorrelation consistent covariance matrix (HAC) methods to produce unbiased and consistent estimators because serial correlation and heteroskedasticity exist. Table 10 reveals the results where model 1 is model with total equity financing and model 2 is model with Mudharabah and Musyarakah. 
Total equity financing positively influences profit but only Musyarakah financing boost profit. The OLS methods are similar to ARDL results. Moreover, the effect of control variables both bank-specific and macroeconomic variables internal, are also the same with ARDL results.

Table 10. OLS regression with robust standard errors

\begin{tabular}{llllll}
\hline \multirow{2}{*}{ Variable } & \multicolumn{2}{c}{ Model 1 } & \multicolumn{2}{c}{ Model 2 } \\
\cline { 2 - 6 } Coefficient & t-Statistic & Variable & Coefficient & t-Statistic \\
PLS & $14.4265^{* * *}$ & 3.8667 & C & $22.9819^{* * *}$ & 2.7807 \\
& $3.1601^{* *}$ & 2.4336 & MUD & -0.0196 & -0.5503 \\
CAR & & & MUS & $0.0418^{* *}$ & 2.5057 \\
OER & -0.0475 & -1.4511 & CAR & -0.0537 & -1.4806 \\
NPF & $-0.0206^{*}$ & -1.5078 & OER & $-0.0199 *$ & -1.4478 \\
LIPI & $-0.2317^{* *}$ & -2.6988 & NPF & $-0.1922^{* *}$ & -2.0866 \\
LEXC & $1.6206^{* *}$ & 1.8042 & LIPI & 0.7831 & 1.2808 \\
R-squared & $-1.9690^{* * *}$ & -2.3741 & LEXC & $-2.4513 * * *$ & -2.3749 \\
\hline
\end{tabular}

Note: $* * *, * *, *$ report significance in $1 \%, 5 \%$, and $10 \%$, respectively

\section{CONCLUSION}

This study explored the extent to which equity financing both Mudharabah and Musyarakah affect the Islamic banks' profitability in Indonesia. This study employed returns on assets (ROA) to measure profitability. The results revealed that equity financing boosted Islamic bank's profitability. However, by splitting equity financing into Mudharabah and Musyarakah, our findings obviously showed that only Musyarakah financing has contributed to profitability. Furthermore, other bank-specific variables such as high capital, low efficiency, and high impaired financing reduced profitability. Economic upturn, as indicated by increasing domestic output and appreciation, has encouraged Islamic banks' profitability.

According to our empirical findings, equity financing, particularly Musyarakah financing, significantly contributes to the profitability of Islamic banks. These findings provide an important policy implication for Islamic banks in maximizing profitability through different types of financing. Islamic banks in Indonesia focused on debt-like financing such as Murabahah financing because it generates a relatively fixed return with less financing risk. This finding shows that equity financing from Musyarakah can encourage Islamic banks' profitability. Therefore, Islamic banks must capitalize on Musyarakah financing so that Musyarakah becomes one of the financing options in Islamic banking. More importantly, this Musyarakah financing will bring back to Islamic banks to their nature to focus on profit-sharing financing. In addition, Islamic banks must also improve the efficiency rate and properly monitor their financing to reduce NPF and increase profits.

However, our study employed aggregate data of Islamic banks and consequently did not reflect the behaviour of individual Islamic banks. Therefore, further study should employ individual bank data, employing panel data regression. 


\section{References}

Ahamed, M. M. (2017). Asset Quality, Non-interest Income, and Bank Profitability: Evidence from Indian banks. Economic Modelling, 63, 114. https://doi.org/10.1016/j.econmod. 2017.01.016.

Aminah, Soewito, Erina, N., Khairudin, \& Damayanti, T. (2019). Financial Performance and Market Share in Indonesia Islamic Banking: Stakeholder Theory Perspective. International Journal of Scientific and Technology Research, 8(1), 1418.

Azmat, S., Skully, M., \& Brown, K. (2015). Can Islamic Banking Ever Become Islamic? Pacific Basin Finance Journal, 34, 253272. https://doi.org/10.1016/j.pacfin.2015.03. 001.

Chen, N., Liang, H. Y., \& Yu, M. T. (2018). Asset Diversification and Bank Performance: Evidence from Three Asian Countries with a Dual Banking System. Pacific Basin Finance Journal, 52(February), 4053. https://doi.org/10.1016/j.pacfin.2018.02.007.

Čihák, M., \& Hesse, H. (2010). Islamic Banks and Financial Stability: An Empirical Analysis. Journal of Financial Services Research, 38(2), 95113. https://doi.org/10.1007/ s10693-010-0089-0.

Hamid, F. S. (2017). The Effect of Market Structure on Banks Profitability and Stability: Evidence from ASEAN-5 Countries. International Economic Journal, 31(4), 578598. https://doi.org/10.1080/10168737.2017.1408668.

Hosen, M. N., \& Rahmawati, R. (2016). Efficiency and Profitability on Indonesian Islamic Banking Industry. Al-Iqtishad: Journal of Islamic Economics, 8(1), 3348. https://doi.org/10.15408/aiq.v8i1.2507.

Ibrahim, M. H., \& Rizvi, S. A. R. (2017). Do We Need Bigger Islamic Banks? An Assessment of Bank Stability. Journal of Multinational Financial Management, 40, 7791. https://doi.org/10.1016/j.mulfin.2017.05.002

Muhammad, R., Suluki, A., \& Nugraheni, P. (2020). Internal Factors and Non-Performing Financing in Indonesian Islamic Rural Banks. Cogent Business and Management, 7(1), 112.https://doi.org/10.1080/23311975.2020.1823583.

Pesaran, M. H., Shin, Y., \& Smith, R. J. (2001). Bounds Testing Approaches to the Analysis of Level Relationships. Journal of Applied Econometrics, 16(3), 289326. https://doi.org/10.1002/jae.616.

Risfandy, T. (2018). Equity Financing and Islamic Banks Profitability: Evidence from the Biggest Muslim Country. Jurnal Keuangan Dan Perbankan, 22(3), 496505. https://doi.org/10.26905/jkdp.v22i3.2150.

Risfandy, T., Harahap, B., Hakim, A. R., Sutaryo, S., Nugroho, L. I., \& Trinugroho, I. (2020). Equity Financing at Islamic Banks: Do Competition and Bank Fundamentals Matter? Emerging Markets Finance and Trade, 56(2), 314328. https://doi.org/10.1080/ 1540496X.2018.1553160.

Setiawan, C., \& Bagaskara, B. (2016). Non-Performing Financing ( NPF ) and Cost Efficiency of Islamic Banks in Indonesia Period 2012Q1 to 2015Q2. Journal of Emerging Issue in Economics, Finance and Banking, 5(1), 18161831. 
Sriyana, J. (2015). Islamic Banks Profitability amid the Competitive Financing in Indonesia. International Journal of Applied Business and Economic Research, 13(4), 16951710.

Sutrisno, \& Widarjono, A. (2018). Maqasid Sharia Index, Banking Risk and Performance Cases in Indonesian Islamic Banks. Asian Economic and Financial Review, 8(9), 11751184. https://doi.org/10.18488/journal.aefr.2018.89.1175.1184.

Trinugroho, I., Agusman, A., \& Tarazi, A. (2014). Why Have Bank Interest Margins been so High in Indonesia since the 1997/1998 Financial Crisis? Research in International Business and Finance, 32, 139158. https://doi.org/10.1016/j.ribaf.2014.04.001.

Trinugroho, I., Risfandy, T., \& Ariefianto, M. D. (2018). Competition, Diversification, and Bank Margins: Evidence from Indonesian Islamic Rural Banks. Borsa Istanbul Review, 18(4), 349358. https://doi.org/10.1016/j.bir.2018.07.006.

Trinugroho, I., Risfandy, T., Ariefianto, M. D., Prabowo, M. A., Purnomo, H., \& Purwaningsih, Y. (2017). Does Religiosity Matter for Islamic Banks Performance? Evidence from Indonesia. International Journal of Economics and Management, $11(2), 419435$.

Warninda, T. D. (2014). Islamic Rural Bank Profitability: Evidence from Indonesia. Journal of Islamic Economics, Banking and Finance, 3, 109122.

Warninda, T. D., Ekaputra, I. A., \& Rokhim, R. (2019). Do Mudarabah and Musharakah Financing Impact Islamic Bank Credit Risk Differently? Research in International Business and Finance, 49, 166175. https://doi.org/10.1016/j.ribaf.2019.03.002.

Widarjono, A. (2018). Estimating Profitability of Islamic Banking in Indonesia. Jurnal Keuangan Dan Perbankan, 22(3), 568579. https://doi.org/10.26905/jkdp.v22i3.2197.

Widarjono, A. (2020). Does the Volatility of Macroeconomic Variables Depress The Profitability of Islamic Banking? Jejak, 13(1), 3042. https://doi.org/10.15294/jejak. v13i1.19460.

Widarjono, A., \& Anto, M. B. H. (2020). Does Market Structure Matter for Islamic Rural Banks Profitability? Jurnal Keuangan Dan Perbankan, 24(4),393406.https://doi.org/ 10.26905/jkdp.v24i4.4810.

Widarjono, A., Anto, M. B. H., \& Fakhrunnas, F. (2020). Financing Risk in Indonesian Islamic Rural Banks: Do Financing Products Matter ? The Journal of Asian Finance, Economics and Business, 7(9), 305314. https://doi.org/10.13106/jafeb.2020.vol7. no9.305.

Widarjono, A., Anto, M. B. H., \& Fakhrunnas, F. (2021). Is Islamic Bank More Stable Than Conventional Bank? Evidence From Islamic Rural Banks in Indonesia. International Journal of Financial Research, 12(2), 294307. https://doi.org/10.5430/ijfr. $\mathrm{v} 12 \mathrm{n} 2 \mathrm{p} 294$.

Widarjono, A., Mifrahi, M. N., \& Perdana, A. R. A. (2020). Determinants of Indonesian Islamic Rural Banks Profitability: Collusive or Non- Collusive Behavior ? The Journal of Asian Finance, Economics and Business, 7(11), 657668. https://doi.org/ 10.13106/jafeb.2020.vol7.no11.657.

Widarjono, A., \& Rudatin, A. (2021). Financing Diversification and Indonesian Islamic Banks Non-Performing Financing. Jurnal Ekonomi \& Keuangan Islam, 7(1), 4558. 